\title{
HIBRID BORDÁZOTT LEMEZEK REZONANCIA VIZSGÁLATA VÉGESELEM-MÓDSZERREL
}

\author{
Virág Zoltán \\ egyetemi docens, Miskolci Egyetem, Bányászati és Geotechnikai Intézet \\ 3515 Miskolc, Miskolc-Egyetemváros, e-mail: gtbvir@uni-miskolc.hu \\ Szirbik Sándor \\ egyetemi docens, Miskolci Egyetem, Müszaki Mechanikai Intézet \\ 3515 Miskolc, Miskolc-Egyetemváros, e-mail: mechsany@uni-miskolc.hu
}

\begin{abstract}
Absztrakt
A hosszirányban nyomott bordázott lemezek többféle numerikus eljárás segitségével is vizsgálhatók. A végeselem analizis (FEA) egy ilyen, igen hatékony numerikus módszer, mely jól alkalmazható lemezszerkezetek esetében is a dinamikai tulajdonságok elemzésére. A vizsgált hibrid merevitett lemez dinamikus hatások által kiváltott viselkedésének vizsgálata modál analízissel kezdödik. A módszer segítségével a szükséges rezonanciaszámitások végezhetök el. A hibrid lemez vizsgálata során feltételeztük azt, hogy az alaplemez és a merevitök Young-modulusa eltérö, feltételezve ezáltal azt, hogy ezek különbözö anyagokból készültek.
\end{abstract}

Kulcsszavak: bordázott lemez, hibrid, végeselem analizis, rezonancia

\begin{abstract}
Longitudinally compressed stiffened plates can be investigated using a variety of methods. Finite element analysis (FEA) is an efficient method, also used to analyze the dynamic behavior of structures. The dynamic behavior of the hybrid stiffened plate can be further investigated by modal analysis. The analysis can be used to perform the resonance calculations required for plate applications. In the hybrid plate test, the Young's modulus of the base plate and the stiffeners are different, assuming that they are made of different materials.
\end{abstract}

Keywords: stiffened plate, hybrid, FEA, resonance

\section{Bevezetés}

Szerkezeti elemek vizsgálatakor leggyakoribb egyszerüsítés a statikus és kvazisztatikus analízis végzése, melyek során a szerkezet a terheléseket lassú ütemben kapja meg, azaz egyensúlyi helyzeteken keresztül terhelődik fel. A kialakuló állandósult állapotban számított mechanikai mennyiségek alapján lesz minősíthető a szerkezet, tehát ez esetben a valóságban lejátszódó folyamat modellezésében az időtől függő hatások elhanyagolása megengedhető. A dinamikus analízis alkalmazása így akkor történik, ha az időtől függő, vagy gyorsulásokból származó hatásokat a modellezés során már nem lehet figyelmen kívül hagyni. Mindkét esetben a megadott terhelési eset (pl. a szerkezeten terhelésként megjelenő erő) és a rendszer válasza (pl. a rendszer elmozdulása a terhelése miatt) közötti kapcsolat leírása fizikai törvényeken alapuló matematikai modellek alapján történik.

A különféle merevített lemezeknél a dinamikus terhelésekre adott válaszok ismerete szintén elengedhetetlen a szerkezetek szakszerü tervezésében, különösen akkor, ha azok környezeti hatásoknak 
például rezgéseknek kitettek. Az időtől függő terhelést szenvedő merevített lemezekkel kapcsolatos problémák számos alkalmazási területen megjelennek a polgári, repülőgépipari, autóipari és tengerhajózási szerkezetek esetén.

A modál analízis, mely során kiszámításra kerülnek a szerkezet saját körfrekvenciái és a hozzájuk tartozó rezgésképek, lesz az alapja a további dinamikus hatásokat is figyelembe vevő vizsgálatoknak, mint például a harmonikus és nemharmonikus gerjesztések esete. Az előfeszített szerkezetek, továbbá nagy szögsebességgel forgó tengelyek és egyéb rezgésre hajlamos alkatrészek modál analízisére is van lehetőség.

A rezgő szerkezet rendelkezik természetes, vagy sajátfrekvenciákkal (a szerkezet rezonanciafrekvenciáival), amelyeken a szerkezet nyugalmi helyzetének megzavarása után magára hagyva rezegni tud. A kialakuló rezgés mértékét, további alakulását a rezgéstani modellben is figyelembe vett csillapítás mértéke befolyásolja. A vonatkozó sajátértékfeladatok megoldása általában a numerikusan pontosabban elvégezhető sajátértékszámítással kezdődik és a sajátértékekhez (saját körfrekvenciákhoz) tartozó sajátvektorok előállításával folytatódik. A sajátértékfeladat numerikus megoldására szolgáló két iterációs technika az altér iteráció és a Lánczos-módszer. Ha a rezgéstani feladat szabadságfoka nagy, akkor a nagyobb numerikus hatékonyságú Lánczos-módszer alkalmazása célravezetőbb [1]. A megoldás részeként kapott sajátrezgések szoftveres [2], képi megjelenítése általában úgy történik, hogy azon a maximális elmozdulás értéke egységnyi, azaz normált - lásd 2. ábrát.

Ha a gerjesztésnek kitett szerkezet gerjesztési frekvenciája egybeesik a sajátfrekvenciák valamelyikével, akkor rezonancia alakul ki, azaz az amplitúdó elméletileg bizonyos idő elteltével aszimptotikusan a végtelenségig növekszik, ami általában kerülendő, mivel ez a valós szerkezetnél a leggyengébb alkotórész törésében jelentkezhet, gátolva így az üzemszerü müködést. Ezért is fontos a sajátfrekvenciák ismerete. A rezonanciakatasztrófa lehetséges veszélyei miatt különféle ipari területeken végeznek is erre vizsgálatokat, pl. bányákban alkalmazott kotrógépeknél $[3,4]$ is.

\section{A vizsgált bordázott lemez kialakítása}

A vizsgálatot egy optimalizált, hosszirányba nyomott, bordázott lemezen végeztük el, melynek elvi vázlata az 1. ábrán látható.

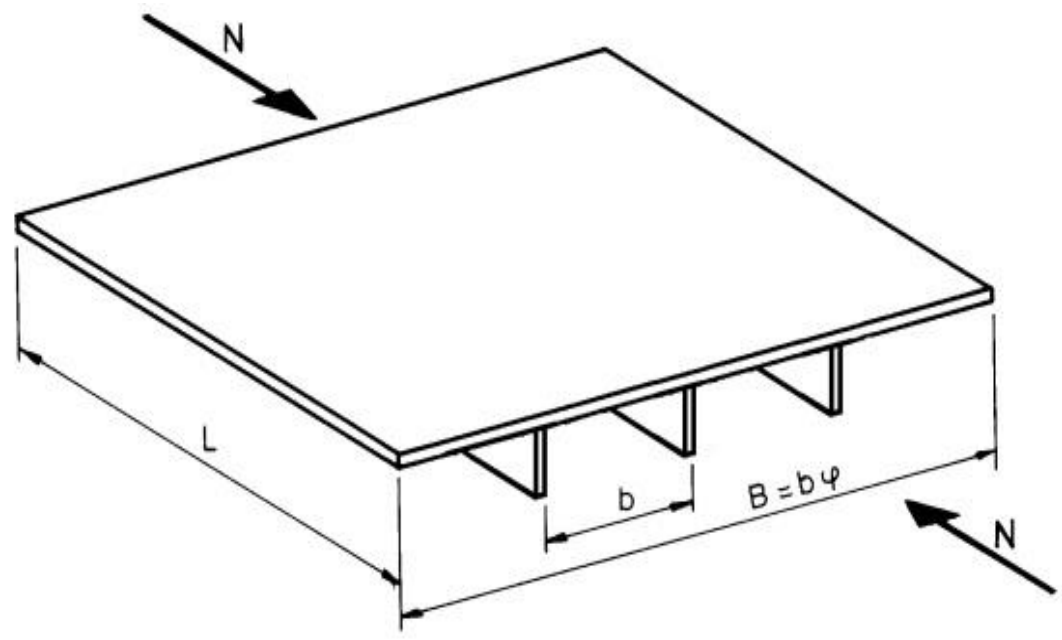

1. ábra. Hosszirányban nyomott bordázott lemez 
A vizsgált szerkezet méretezésekor a következő tervezési feltételeket kell figyelembe venni [5]:

- Bordázott lemez horpadási feltétele. A horpadási görbében figyelembe vesszük a lemez gyártása során megmaradó hegesztési feszültség és a szerkezet kezdeti alakpontatlanság hatását is.

- Alaplemez horpadási feltétele. Az alaplemez bordák közötti helyi horpadására írható fel ez a vizsgálat.

- Bordák helyi horpadása és elcsavaródó kihajlási feltétele. A bordák helyi horpadását a határkarcsúsággal változtatásával vesszük figyelembe különféle bordaalakok esetén. Ez egy olyan instabilitási feltétel, amely a vizsgált lemez geometriájától jelentősen függ.

- Alakváltozási feltétel. A lemez teljes hosszán végigfutó hegesztésből származó alakváltozás nagyságának a korlátozását jelenti a lemezhosszúságához viszonyítva.

A bordázott lemezt optimáltuk, ahol a minimálandó célfüggvény az anyagköltség volt. Az optimálás kiinduló adatai pedig a következők voltak: alaplemez szélesség $B=6000[\mathrm{~mm}]$, alaplemez hosszúság $\mathrm{L}=4000[\mathrm{~mm}]$, nyomási erő $\mathrm{N}=1,2 \times 10^{7}[\mathrm{~N}]$, Young modulus $\mathrm{E}=210[\mathrm{GPa}$ ], sürüség $\rho=7,85 \mathrm{x}$ $10^{-6}\left[\mathrm{~kg} / \mathrm{mm}^{3}\right]$, a folyáshatár $\mathrm{f}_{\mathrm{y}}=235[\mathrm{MPa}]$. Az optimálást Excel Solver NLP programmal végeztük, amely gradiens módszer alkalmaz. A számítások során az ismeretlenek az alaplemez $\left(t_{f}\right)$ és a borda $\left(t_{s}\right)$ vastagsága, illetve a bordák száma $(\varphi-1)$, melyek értékei csak bizonyos határon belül mozoghatnak. A végzett optimálások eredményei közül kiválasztva, az anyagköltségre végzett számítás egyik eredményét az 1. táblázat foglalja össze a geometriai kialakítás paraméterei tekintetében.

1. táblázat. Az optimált lemez

\begin{tabular}{|c|c|c|c|}
\hline$t_{f}[\mathrm{~mm}]$ & $t_{s}[\mathrm{~mm}]$ & $\varphi$ & $K / k_{m}[\mathrm{~kg}]$ \\
\hline 5 & 10 & 29 & 2172 \\
\hline
\end{tabular}

\section{A hibrid bordázott lemez rezonancia vizsgálata}

Különbözö tulajdonságú anyagok együttes használata nem újkeletü, hiszen használják pl. kompozit szendvicsszerkezeteknél is, amelyekre szintél alkalmaznak optimalizálást [6, 7]. A hibrid lemez vizsgálata során az alaplemez és a merevítők Young-modulusa különbözö, feltételezve azt, hogy ezek különböző anyagokból készültek.

A vizsgált bordázott lemez geometriai adatait az 1. táblázat foglalja össze. Az alábbiakban az egyszerü megtámasztással (simply supported) ellátott lemez végeselemes rezgéstani vizsgálatai kerülnek bemutatásra. A választott kialakításnál végeselemes számítások útján határoztuk meg az első néhány sajátfrekvenciát, valamint a hozzájuk tartozó rezgésképeket. A szabad rezgések ezeken a diszkrét frekvenciákon fordulnak elö, a geometriától és az anyagtól függenek, melyet továbbá az alkalmazott alátámasztás döntően befolyásol, a terhelés pedig szemben stabilitásvesztés vizsgálatokkal nem $[5,8]$.

A numerikus mechanika végeselem-módszere a szerkezet pontos geometriai modelljének egyszerü alakú és véges számú, elég kicsiny elemre történő felosztásán alapul. Az általunk használt végeselemes elemcsaládok adott számú oldalélből és általában azokon elhelyezkedő csomópontokból állnak. Egyes elemek a valóságos kapcsolódásoknak megfelelően illeszkednek egymáshoz az elemek határain kijelölt csomópontokban tett, illetve az illeszkedő csomópontok elmozdulásaiban történő előírások felhasználásával. Héjmodellt alkalmazva a merevítőket és az alaplemezt is végeselemekre osztott az analízishez (FEA). A végeselemes eljárások elméleti háttere részletekbe menően megtalálható Bathe könyvében [1].

Az első nyolc sajátfrekvencia előállítása Abaqus szoftver [2] segítségével héjelemek alkalmazása mellett lineáris perturbációval történt. Az egyszerüség végett a bordás lemez végeselemes modellezé- 
séhez egy széleskörben használatos, hagyományos elemcsaládot választottunk, a lineáris 4 csomópontú S4R jelü héjelemet, mely kellő elemszám mellett már megfelelő pontosságot biztosít. Az FE modell így 8150 lineáris héjelemet tartalmaz, mert az átlagos elemméret $70[\mathrm{~mm}]$ nagyságúnak választott. A végeselemes modellhez rendelt lineáris anyagtörvényeket a borda, illetve alaplemez tulajdonságainak megfelelően írtuk elő. Első számítási sorozatban a merevítőbordák rugalmassági vagy Youngmodulusának módosítása történt meg miközben az alaplemez anyagát változatlan, azaz 210 [GPa] nagyságú modulussal számoltuk, majd a második számítási sorozatban a bordák Young-modulusát változatlanul, $210[\mathrm{GPa}]$ értékünek hagyva a lemez anyagát leíró modulust változtattuk meg. A Poisson-szám értéke pedig minden vizsgált esetben változatlanul 0,25 értékü maradt. Az első nyolc természetes vagy saját körfrekvenciát a 2. és 3. táblázat tartalmazza. A 2. táblázatban látható módon az öszszetartozó sorszámú saját körfrekvenciák csökkenése arányos és összhangban van a merevítőbordák anyagát leíró rugalmassági modulus csökkenésével az alaplemez változatlan 210 [GPa] értékủ modulusa mellett.

2. táblázat. Saját körfrekvenciák [rad/s] összehasonlitása $E=210$ [GPa] alaplemez esetén

\begin{tabular}{|c|c|c|c|}
\hline \multirow{2}{*}{ Mode No } & \multicolumn{3}{|c|}{ Bordák Young-modulusa [GPa] } \\
\cline { 2 - 4 } & 210 & 200 & 190 \\
\hline 1. & 142,57 & 140,35 & 138,04 \\
\hline 2. & 147,14 & 144,80 & 142,37 \\
\hline 3. & 159,08 & 156,33 & 153,47 \\
\hline 4. & 168,85 & 165,72 & 162,47 \\
\hline 5. & 177,06 & 173,65 & 170,11 \\
\hline 6. & 184,65 & 181,08 & 177,39 \\
\hline 7. & 192,89 & 189,27 & 185,53 \\
\hline 8. & 202,60 & 199,01 & 195,32 \\
\hline
\end{tabular}

A 3. táblázatban összefoglalt saját körfrekvenciák is a lemez rugalmassági modulusának csökkenésével együtt, arányosan csökkennek az összetartozó sorszámúaknál, miközben ellentétben az elöbbi esettel itt a borda anyagát jellemző Young-modulus marad változatlan 210 [GPa] értékü.

3. táblázat. Saját körfrekvenciák [rad/s] összehasonlitása $E=210$ [GPa] borda esetén

\begin{tabular}{|c|c|c|c|}
\hline \multirow{2}{*}{ Mode No } & \multicolumn{3}{|c|}{ Alaplemez Young-modulusa [GPa] } \\
\cline { 2 - 4 } & 210 & 200 & 190 \\
\hline 1. & 142,57 & 141,32 & 140,00 \\
\hline 2. & 147,14 & 145,89 & 144,58 \\
\hline 3. & 159,08 & 157,95 & 156,75 \\
\hline 4. & 168,85 & 167,88 & 166.84 \\
\hline 5. & 177,06 & 176,17 & 175,22 \\
\hline 6. & 184,65 & 183,75 & 182,80 \\
\hline 7. & 192,89 & 191,86 & 190,78 \\
\hline 8. & 202,60 & 201,30 & 199,97 \\
\hline
\end{tabular}


Összehasonlítva a 2. és 3. jelü összefoglaló táblázatban közölt eredményeket, azt tapasztaljuk, hogy a bordák anyagának változása jobban befolyásolja a frekvenciákat, mint az alaplemezben bekövetkező hasonló változás. A bordák megfelelő száma és a szerkezet megfelelő minőségben történő gyártása mellett az anyagminőség is döntő befolyással bír tehát a terhelhetőség szempontjából.

Az első négy sajátfrekvenciához tartozó rezgésképek a 2. ábrán látható módon kerülnek megjelenítésre. A két számítási sorozat eredményei nagyfokú hasonlóságot mutatnak, ezért csak az első számítási sorozathoz tartozó egyik modulus pár eredményeit mutatjuk meg.
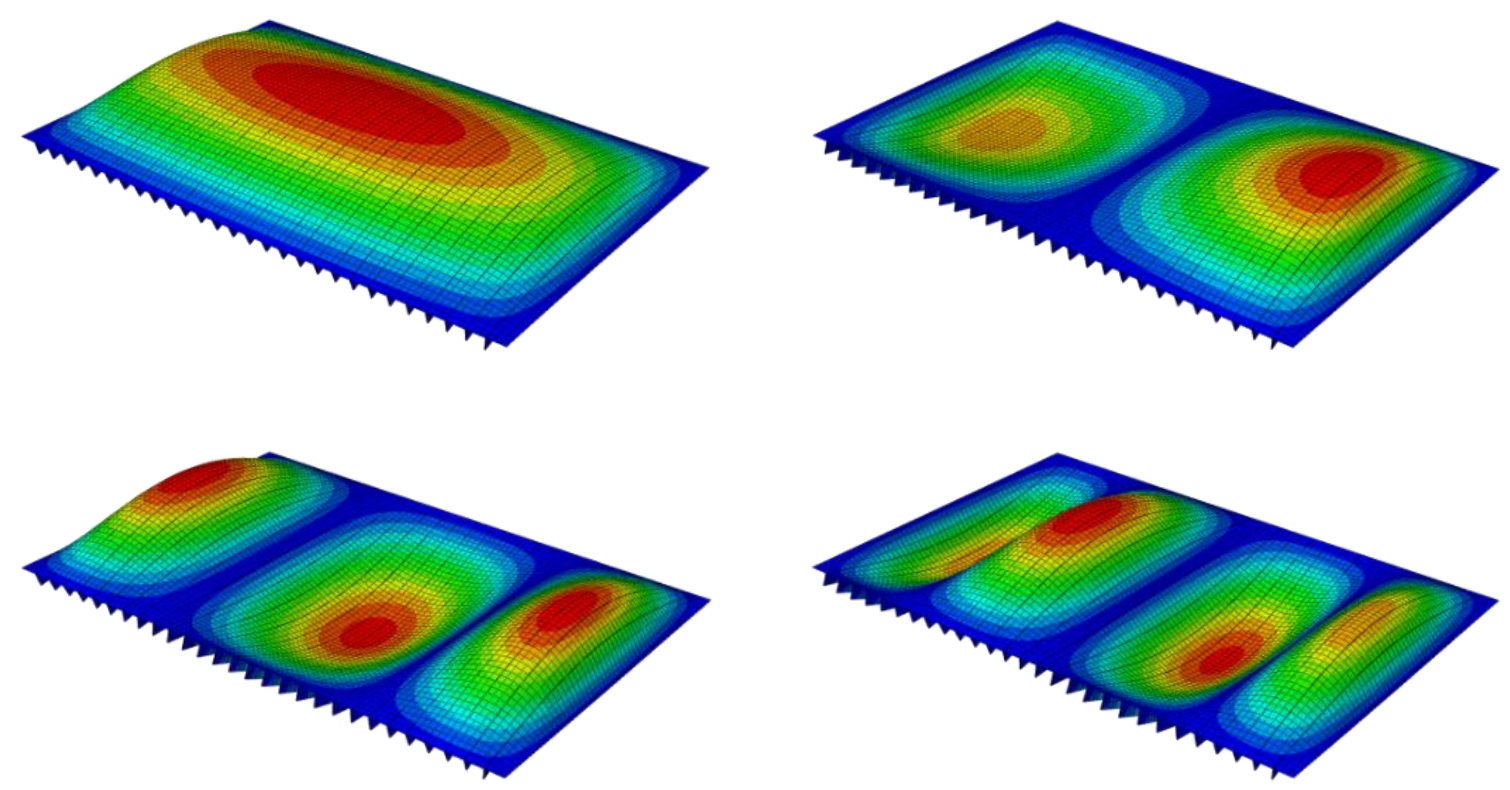

2. ábra. A bordázott lemez elsö négy rezgésképe

A sajátrezgésképek jobb szemléltetése érdekében a szoftver [2] kéktől piros színig terjedő színskálát alkalmaz a deformált alakon, amely szerint a maximális és abszolútértékben egységnyi elmozdulás megjelenítésekor a piros, míg a nulla mértékü elmozdulásnál a kék szín festi a 2. ábrát. Az időtől függő terhelésnek kitett lemez vizsgálatára hatékony modus szuperpozíciós eljárások pedig a modál analízisből előálló, sorrendben első néhány (1-8) sajátrezgést veszik alapul.

\section{4. Összefoglalás}

A cikkben hibrid bordázott lemezek vizsgálatát mutattuk be, amely során feltevésünk, hogy a szerkezet két fö alkotóeleme (az alaplemez és a merevitőbordák) különböző anyagokból készülnek, amelyeket a legegyszerü módon különböző Young modulussal írunk le. Az eredmények nagyobb, de arányos eltéréseket mutatnak, ha a merevítők modulusában történik változás. A lemezszerkezet megfelelő tervezésén túlmenően tehát a megfelelő anyagminőség is fontos. A dinamikus terhelések merevített lemezekre gyakorolt hatása a modál analízis eredményeit használó modus szuperpozíciós technikákkal tovább vizsgálható. A numerikus mechanika végeselem-módszere pedig ez esetben is nagyon jól használható eszköz. 


\section{Köszönetnyilvánítás}

A cikkben ismertetett kutató munka az EFOP-3.6.1-16-2016-00011 jelü „Fiatalodó és Megújuló Egyetem - Innovatív Tudásváros - a Miskolci Egyetem intelligens szakosodást szolgáló intézményi fejlesztése" projekt részeként - a Széchenyi 2020 keretében - az Európai Unió támogatásával, az Európai Szociális Alap társfinanszírozásával valósul meg.

\section{Irodalom}

[1] Bathe, K. J.: Finite element procedures, Prentice-Hall Inc. Englewood Cliffs, New Jersey, 1996.

[2] Abaqus 6.13 online documentation, Dassault Systems, 2015.

[3] Popescu, F. D., Radu, S. M., Andras, A., Kertesz (Brînaș), I.: Simulation of the frequency response of the ERC 1400 Bucket Wheel Excavator boom, during the excavation process, New Trends in Production Engineering, Vol. 2, Issue 1, (2019) pp. 153-167. https://doi.org/10.2478/ntpe-2019-0016

[4] Radu, S. M., Popescu, F. D., Andras, A., Kertesz (Brînaș), I., Tomus, O. B.: Simulation and modelling of the forces acting on the rotor shaft of BWEs, in order to improve the quality of the cutting process, Annals of the University of Petroşani, Mechanical Engineering, Vol. 20, (2018) pp. 63-72.

[5] Virág, Z., Szirbik, S.: Natural frequencies and mode shapes of optimized stiffened plates, 2019 MultiScience - XXXIII. microCAD International Multidisciplinary Scientific Conference, University of Miskolc, 23-24 May, D2_9_Virag_Zoltan.pdf, 9 p. https://doi.org/10.26649/musci.2019.056

[6] Kovács, Gy.: Optimization of structural elements of transport vehicles in order to reduce weight and fuel consumption, Structural Engineering and Mechanics, Vol 71, Issue 3, (2019) pp. 283-290.

[7] Kovács, Gy., Farkas, J.: Optimal design of a composite sandwich structure, Science and Engineering of Composite Materials, Vol 23, Issue 2, (2016) pp. 237-243. https://doi.org/10.1515/secm-2014-0186

[8] Mukherjee, A., Mukhopadhyay, M.: Finite element free vibration analysis of stiffened plates, The Aeronautical Journal, (1986) pp. 267-273. 